\title{
MAKAM-MAKAM KUNO DI TASIKMALAYA Latar Belakang Konsep dan Tokoh
}

\author{
Ancient Tombs in Tasikmalaya: Background Concepts and Figures
}

\author{
Endang Widyastuti ${ }^{1)}$ dan Nanang Saptono ${ }^{2)}$ \\ Balai Arkeologi Jawa Barat \\ Jl. Raya Cinunuk Km. 17 Cileunyi Bandung \\ 1) Email: endangwidyastuti6@gmail.com \\ 2) Email: nanangsaptono@gmail.com
}

Naskah diterima: 20 Maret 2019 Revisi terakhir: 20 Juni 2019

Disetujui terbit: 15 Juli 2019 - Tersedia secara online: 30 Juli 2019

\begin{abstract}
In the Tasikmalaya area many sites are found in the form of tombs and ancient grave complexes from the Islamic era. In archaeological studies, the tomb can be interpreted as a place where the body is buried and also the former location of the event by an important figure. The tomb can be interpreted as a grave and also petilasan. Through the tomb data can be revealed various aspects such as background concepts and figures buried. This study of ancient tombs in Tasikmalaya aims to reveal the background of the concept of site selection and the background of the buried figure. The research method is qualitative research through descriptive type. Disclosure of research problems is obtained through literature study and trace data reinforcement in the form of manuscripts. Ancient tombs in Tasikmalaya are on the plain and on top of a hill. The tomb at the top of the hill shows the continuity of previous cultural concepts, namely that high ground in the form of a hill or mountain is a sacred place. Some figures who are buried have a big role in the welfare of the community in the past, namely the opening of the Cibeureum situ.
\end{abstract}

Keywords: grave, manuscript, persons, lake

\begin{abstract}
Abstrak
Di daerah Tasikmalaya banyak dijumpai situs berupa makam dan kompleks makam kuno dari masa Islam. Dalam studi arkeologi makam dapat dimaknai sebagai tempat mayat dikubur dan juga bekas lokasi terjadinya peristiwa yang dilakukan oleh tokoh penting. Makam dapat diartikan sebagai kubur dan juga petilasan. Melalui data makam dapat diungkap berbagai aspek misalnya latar belakang konsep dan tokoh yang dimakamkan. Kajian tentang makam kuno di Tasikmalaya ini bertujuan untuk mengungkap latar belakang konsep pemilihan lokasi dan latar belakang tokoh yang dimakamkan. Metode penelitian berupa penelitian kualitatif melalui tipe deskriptif. Pengungkapan permasalahan penelitian diperoleh melalui studi pustaka dan penelusuran data penguat berupa naskah. Makammakam kuno di Tasikmalaya berada di pedataran dan puncak bukit. Makam yang berada di puncak bukit menunjukkan adanya kesinambungan konsep budaya prasejarah yaitu bahwa tanah tinggi berupa bukit atau gunung merupakan tempat suci. Beberapa tokoh yang dimakamkan mempunyai peranan besar dalam kesejahteraan masyarakat pada masa lalu yaitu seputar pembukaan situ Cibeureum.
\end{abstract}

Kata kunci: kubur, makam, naskah, tokoh, situ 


\section{PENDAHULUAN}

Budaya manusia terkait dengan perjalanan hidup yaitu lahir, tumbuh, dan mati. Pada masing-masing tahapan tersebut akan diliputi wujud-wujud budaya baik berupa gagasan atau ide, tingkah laku, dan benda hasil ciptaan. Kematian sebagai akhir dari perjalanan hidup manusia banyak menyimpan budaya. Berdasarkan bukti-bukti arkeologi, aktivitas budaya dalam kaitannya dengan kematian baru muncul pada masa berburu dan mengumpulkan makanan tingkat lanjut hingga masa bercocok tanam. Bukti tentang penguburan ditemukan di Gua Lawa, Sampung dan Gua Sodong serta di bukitbukit kerang Sumatera Utara. Di antara mayat-mayat itu ada yang ditaburi oker merah. Cat merah dari bahan oker yang ditaburkan berhubungan dengan upacara penguburan. Tujuan upacara tersebut agar memberikan kehidupan baru di alam baka (Poesponegoro dan Notosusanto, 2009a).

Penguburan merupakan salah satu cara dalam memperlakukan mayat. Selain mengubur, cara lain yang lazim adalah membakar. Cara lain untuk menyingkirkan mayat dalam keadaan darurat misalnya menenggelamkan ke dasar laut (Nurhadi, 1990: 138). Cara unik dalam memperlakukan mayat adalah meletakkannya begitu saja pada tempat tertentu sebagaimana yang dilakukan oleh masyarakat Trunyan, Bali. Mayat diletakkan di atas tanah pada lokasi yang telah ditentukan dengan hanya ditutup dengan bambu. Jumlah tempat untuk meletakkan mayat ada 11 tempat. Bagi masyarakat Bali bilangan 11 merupakan bilangan tertinggi yang sakral dan merupakan puncak pencapaian spiritual. Bilangan 11 juga diyakini sebagai 11 tingkatan mulai dunia hingga nirwana (Umiarti dan Sukana, 2016: 8).

Penguburan merupakan serangkaian aktivitas mulai dari menggali atau mempersiapkan liang lahat, meletakkan mayat pada tepatnya, menimbun, dan kemudian memberi tanda agar diketahui umum (Nurhadi, 1990: 138). Pengertian kubur dalam Islam berhubungan dengan kewajiban kaum muslimin terhadap orang yang meninggal dunia. Kewajiban tersebut hukumnya fardhu kifayah, artinya apabila sebagian dari kaum muslimin sudah mengerjakannya maka terlepaslah yang lain dari kewajiban itu, tetapi bila tidak ada satu orang pun dari kaum muslimin yang mengerjakannya maka semuanya berdosa. Kewajiban tersebut terdiri dari mensucikan (memandikan), mengafani (membungkus), menyolatkan, dan menguburkan atau menanamkan. Kedalaman kubur dibuat sedemikian rupa sehingga bau busuk mayat tidak tercium dari atas kubur dan tidak dapat dibongkar oleh binatang buas. Lubang kubur disunatkan memakai liang lahat. Beberapa anjuran yang berhubungan dengan kubur antara lain ditinggikan dari tanah sekitar kira-kira sejengkal. Hal ini didasarkan pada hadits yang diriwayatkan oleh Baihaqi. Kubur sebaiknya ditandai dengan batu atau lainnya pada bagian kepala mayat. Hal ini didasarkan pada hadits yang diriwayatkan oleh Abu Dawud (Rasjid, 1992: 161178). Pada beberapa hadits disebutkan bahwa kubur lebih baik ditinggikan dari tanah di sekitarnya tetapi tidak dimunjungkan agar mudah dikenali (Ambary, 1991: 5-6).

Secara arkeologis, kubur sebagai data terdiri dari dua bagian yaitu bagian yang terkubur di dalam tanah dan bagian yang tampak di permukaannya. Data yang terkubur meliputi liang lahat, mayat atau rangka, dan benda-benda penyerta termasuk bekal kubur. 
Data yang tampak di permukaan meliputi tanda berupa nisan dan atau jirat. Pada beberapa kasus juga dilengkapi bangunan pelindung atau cungkup (Nurhadi, 1990: 139). Kubur seringkali juga disebut dengan makam. Makam selain dipahami sebagai kubur, juga berarti tempat tinggal, kediaman, atau persemayaman (Redaksi, 2005). Dengan demikian istilah "makam" selain diartikan kubur dapat juga diartikan sebagai kediaman atau persemayaman. Dalam Islam pengertian makam berbeda dengan pengertian kuburan. Makam dapat diartikan sebagai bekas tanda atau petilasan.

Melalui aspek arkeologi, makam kuno dapat dijadikan sebagai media untuk mengungkapkan beberapa hal yang berkaitan dengan identitas tokoh, pola penempatan, identifikasi motif hias, kronologi, dan latar belakang budaya masyarakat pendukungnya pada masa lampau (Suhadi dan Hambali, 1995). Objek arkeologi berupa makam banyak ditemukan terutama pada masyarakat yang budayanya dilatarbelakangi agama Islam, Kristen, Protestan atau agama dan kepercayaan lain seperti Kong $\mathrm{Hu} \mathrm{Cu}$ dan agamaagama asli nusantara. Di kawasan Tasikmalaya banyak dijumpai makam-makam dari zaman Islam (Tim Penelitian, 2012). Di Kelurahan Empangsari, Kecamatan Tawang terdapat situs Gunung Dalem. Situs berada pada bukit yang dikelilingi permukiman penduduk. Pada situs tersebut terdapat makam Mbah Dalem Subhantaka yang merupakan tokoh penguasa wilayah. Selain situs Gunung Dalem, di Kelurahan Empangsari juga terdapat makam lainnya yaitu makam Komara yang juga merupakan pemimpin yang disegani. Di Kelurahan Bantarsari, Kecamatan Bungursari terdapat pemakaman umum Cieunteung. Di kompleks makam tersebut terdapat makam kuno. Tokoh yang dimakamkan Eyang Kertarajasakti atau dikenal juga dengan sebutan Mbah Jambrong. Tokoh ini merupakan sesepuh masyarakat Bantarsari. Di kompleks makam Cieunteung juga terdapat makam tokoh berkebangsaan Eropa bernama S. Hamar De La Brethoinere. Selain tokoh pemimpin, juga terdapat makam penyebar Islam. Di Kelurahan Gunung Gede, Kecamatan Kawalu terdapat makam K.H. Syech Abdul Ghorib. Selain itu di di Blok Meunggeur, Kampung Sukabetah, Kelurahan Sukaasih, Kecamatan Purbaratu, terdapat kompleks makam kuno zaman Islam yang dikeramatkan masyarakat. Tokoh utama yang dimakamkan adalah Syech Tubagus Abdullah yang merupakan tokoh penyebar agama Islam. Pada kompleks makam tersebut, selain Syech Tubagus Abdullah juga terdapat makam Balung Tunggal (Widyastuti dan Boedi, 2018).

Di daerah Tasikmalaya bagian selatan juga banyak dijumpai makam-makam tokoh dari zaman Islam. Dalam kegiatan peninjauan yang dilakukan pada akhir tahun 2018 yang lalu diperoleh informasi adanya beberapa makam kuna. Makam-makam tersebut adalah kompleks makam Gunung Gede, di Babakan Tempe, Kelurahan Sambongjaya, Kecamatan Mangkubumi; Kompleks Makam Gunung Subang di Kelurahan Leuwiliang, Kecamatan Kawalu; kompleks Makam Eyang Bagus Entol; dan kompleks makam Blok Nusa Tamansari, Kelurahan Tamanjaya, Kecamatan Tamansari. Secara umum tujuan dari tulisan ini dimaksudkan untuk mengetahui lebih jelas keberadaan tinggalan-tinggalan arkeologis tersebut dan kaitannya dengan latar kehidupan masyarakat masa lalu yang bermukim di wilayah tersebut. Selain itu juga akan diungkap peranan tokoh-tokoh yang dimakamkan. Pengumpulan data dilakukan dalam bentuk 
observasi langsung di lapangan. Dalam mencari dan melengkapi informasi yang dibutuhkan juga dilakukan wawancara terhadap masyarakat, tokoh adat dan pemuka masyarakat yang tinggal wilayah tersebut.

\section{HASIL DAN PEMBAHASAN}

\section{Kondisi Lingkungan}

Kota Tasikmalaya berdasarkan bentang alamnya berada pada daerah dengan ketinggian berkisar antara 201-503 $\mathrm{m}$ di atas permukaan laut (dpl) dan mempunyai dataran dengan kemiringan relatif kecil. Daerah tertinggi berada di Kelurahan Bungursari, Kecamatan Bungursari (kaki G. Galunggung) yaitu $503 \mathrm{~m}$ dpl sedangkan yang terendah berada di Kelurahan Urug, Kecamatan Kawalu yaitu sekitar 201 m dpl. Ditinjau dari segi fisiografi wilayah, tempat tertinggi Kota Tasikmalaya terdapat di bagian barat dan selatan, kemudian menurun ke tengah di sekitar pusat kota menuju utara serta sebagian kecil dari timur ke tengah dan utara Kota Tasikmalaya. Pada bagian selatan wilayah Kota Tasikmalaya, di sekitar Kecamatan Kawalu dan Cibeureum, kondisinya cenderung berbukit-bukit dengan ciri hutan dan kebun campuran. Secara geologis, Kota Tasikmalaya terletak di kawasan perbukitan dan gunung api tua. Struktur geologi Kota Tasikmalaya terbentuk dari material dasar berupa batuan induk vulkanik, yaitu susunan batuan yang terdiri dari breksi vulkanik termampat lemah dengan bongkah lava andesit yang dihasilkan pada tingkat gunung api tua. Batuan ini tersebar merata, menutupi hampir seluruh wilayah Kota Tasikmalaya (Kondisi Geografi Kota Tasikmalaya, 2018). Objek makam-makam kuno dalam kajian ini berada di bagian selatan Kota Tasikmalaya.

\section{Keadaan Objek}

Kompleks Makam Gunung Subang

Makam Gunung Subang berada di Bukit (Pasir) Waisa yang secara administratif terletak di Kampung Gunung Subang, Kelurahan Cilamajang, Kecamatan Kawalu. Lokasi ini secara geografis terletak pada posisi $7^{\circ} 22 ' 21.66^{\prime \prime}$ Lintang Selatan dan $108^{\circ} 11^{\prime} 42.43^{\prime \prime}$ Bujur Timur. Sekeliling bukit merupakan pemukiman penduduk yang cukup padat.

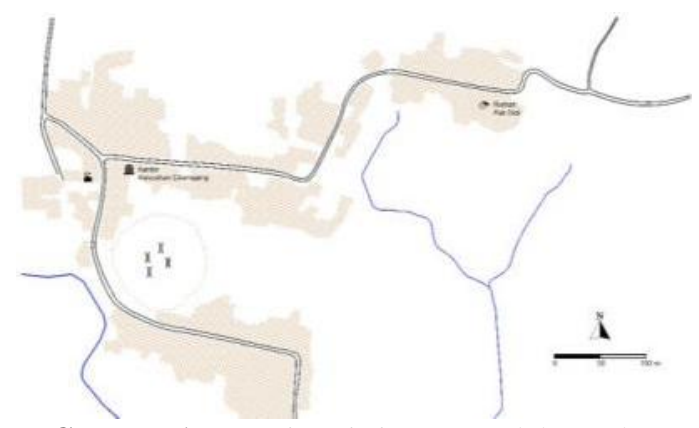

Gambar 1. Peta situasi situs Kompleks Makam Gunung Subang (Sumber: Dokumen Balai Arkeologi Jawa Barat, 2018)

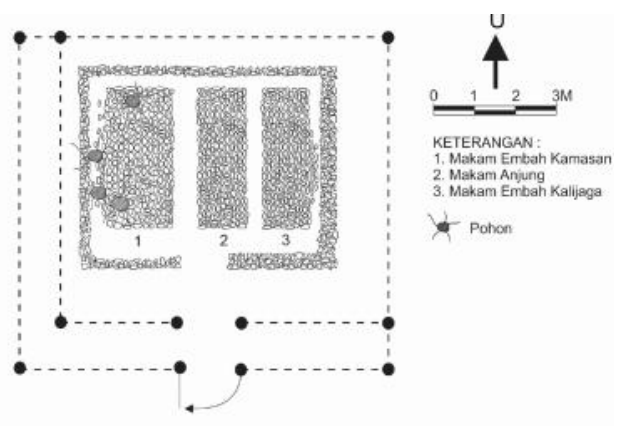

Gambar 2. Denah situs Kompleks Makam Gunung Subang (Sumber: Dokumen Balai Arkeologi Jawa Barat, 2018) 
Puncak Bukit Waisa merupakan kompleks pemakaman umum. Pada bagian tertinggi terdapat tiga makam yang berpagar besi. Pagar besi terdiri dari dua lapis. Pagar bagian luar berukuran $9 \times 8 \mathrm{~m}$, sedangkan bagian dalam berukuran $8 \times 7 \mathrm{~m}$. Pagar besi tersebut dibuat oleh Dinas Kepemudaan, Olahraga, Kebudayaan dan Pariwisata Kota Tasikmalaya. Pada bagian dalam pagar besi tersebut terdapat 3 makam yang berjajar barat - timur. Ke 3 (tiga) makam tersebut menurut informasi dari kuncen setempat merupakan makam dari Embah Kamasan, Embah Anjung, dan Embah Kalijaga. Jirat ketiga makam berupa batu alam tanpa pengerjaan yang disusun membentuk persegi panjang berukuran 3,5 x $1 \mathrm{~m}$. Ketiga makam dilengkapi nisan yang terbuat dari batu alam tanpa pengerjaan dan diletakkan dengan posisi tegak.

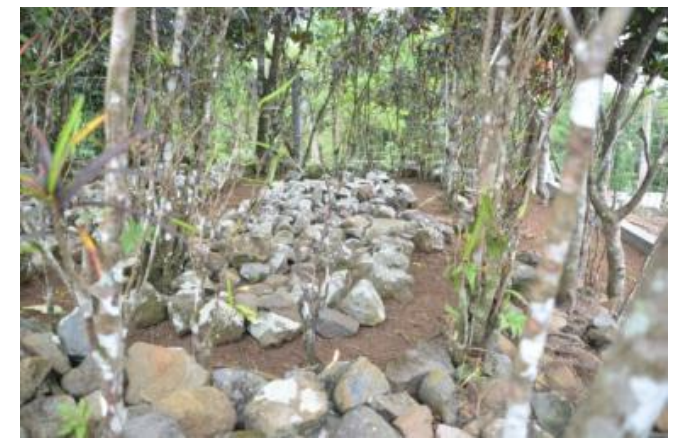

Gambar 3. Salah satu makam di kompleks makam Gunung Subang (Sumber: Dokumen Balai Arkeologi Jawa Barat, 2018)

\section{Kompleks Makam Babakan Tempe}

Kompleks Makam Babakan Tempe berada di sebuah bukit yang disebut Pasir Limus. Secara administratif kompleks makam ini berada di Kampung Sukasari RT 05/05, Kelurahan Sambongjaya, Kecamatan Mangkubumi. Secara geografis lokasi berada di $7^{\circ} 21^{\prime} 36.18^{\prime \prime}$ LS dan 108²'25.67" BT. Di sebelah timur dan selatan kompleks makam terdapat pemukiman penduduk, sedangkan di sebelah utara dan barat merupakan lahan persawahan. Di sebelah utara kompleks makam mengalir Ci Sambong. Di lokasi ini terdapat dua bukit yang saling bersebelahan. Menurut keterangan kuncen bukit yang berada di sebelah timur laut disebut Pasir Limus, sedangkan bukit yang berada di sebelah barat daya disebut Gunung Gede. Masih menurut kuncen, kompleks makam Babakan Tempe berada di Pasir Limus.

Pada bagian atas Bukit (Pasir) Limus terdapat kompleks makam kuno. Tokoh utama yang dimakamkan berjumlah 3 (tiga) orang. Menurut informasi, tokoh utama yang dimakamkan adalah Amirudin, Embah Nangga dan Amburudin. Di sekitar makam tokoh utama terdapat beberapa makam yang tidak diketahui tokohnya. Makam-makam utama berorientasi utara selatan, berjajar barat - timur. 


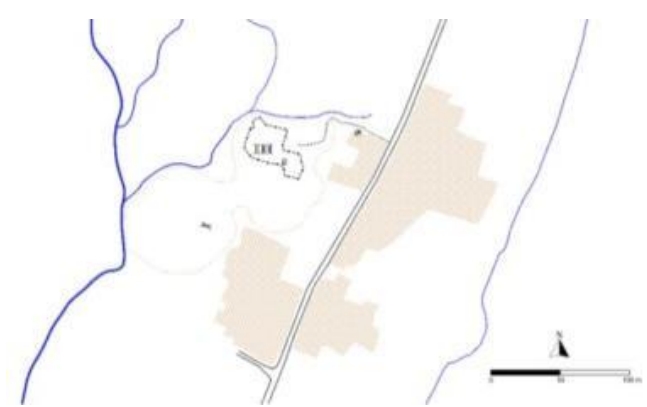

Gambar 4. Peta situasi situs Kompleks Makam Babakan Tempe (Sumber: Dokumen Balai Arkeologi Jawa Barat, 2018)

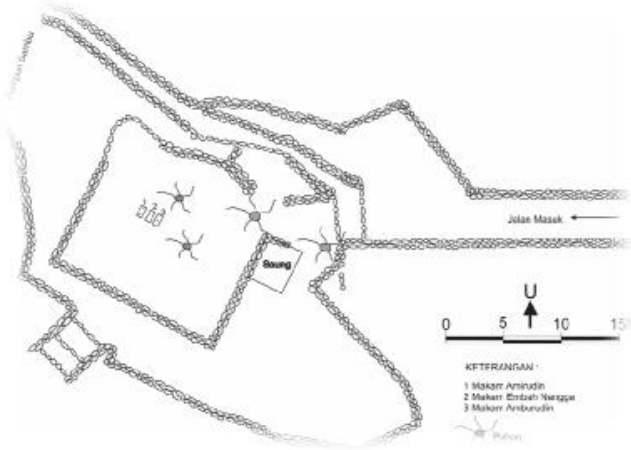

Gambar 5. Denah komplek Makam Babakan Tempe (Sumber: Dokumen Balai Arkeologi Jawa Barat, 2018)

Ketiga makam utama tersusun dari batu alam tanpa pengerjaan yang diatur membentuk jirat. Makam Amirudin berada paling barat berukuran 200 x $85 \mathrm{~cm}$. Makam dilengkapi 2 buah nisan yang terbuat dari batu alam tanpa pengerjaan. Ukuran nisan sebelah utara tinggi: $55 \mathrm{~cm}$, lebar: $33 \mathrm{~cm}$, dan tebal: $9 \mathrm{~cm}$, nisan sebelah selatan adalah tinggi: $45 \mathrm{~cm}$, lebar: $30 \mathrm{~cm}$, dan tebal: 11,5 cm. Makam Embah Nangga berada di tengah dengan ukuran jirat 225 x $100 \mathrm{~cm}$, tanpa nisan. Sedang Makam Amburudin berada paling timur dengan ukuran jirat 175 x $60 \mathrm{~cm}$. Makam dilengkapi nisan berjumlah satu berada di bagian tengah.

Di sekeliling ketiga makam utama terdapat makam-makam yang ditandai dengan nisan dari batu alam tanpa pengerjaan yang diletakkan dengan posisi tegak. Makammakam tersebut tidak diketahui siapa tokohnya. Menurut keterangan juru kunci, tatanan batu di bagian selatan lahan merupakan tambahan yang dibuat oleh juru kunci sebelumnya. Pada teras bagian bawah, terutama di lereng selatan merupakan pemakaman umum yang hingga sekarang masih dipergunakan.

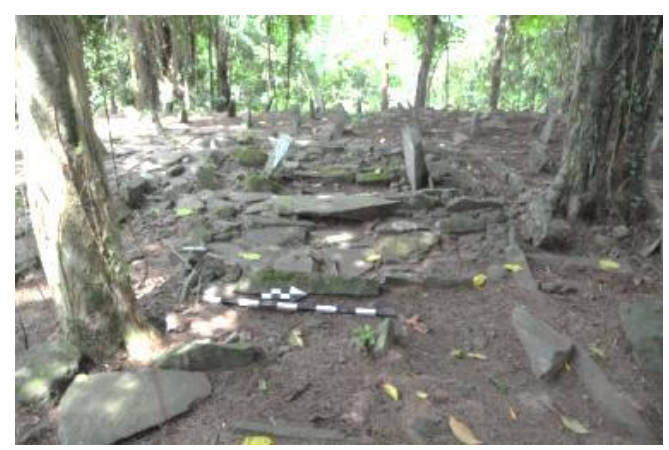

Gambar 6. Kompleks Makam Babakan Tempe (Sumber: Dokumen Balai Arkeologi Jawa Barat, 2018)

Di sebelah barat daya Pasir Limus berjarak sekitar $85 \mathrm{~m}$ terdapat puncak Gunung Gede. Dari Pasir Limus menuju Gunung Gede terdapat jalan setapak melewati lembah. Lahan di Gunung Gede berupa kebun yang kurang terawat. Pada lahan terdapat beberapa 
makam baru yang kondisinya juga kurang terawat. Pada lereng tenggara terdapat makam dengan nisan batu berorientasi barat laut - tenggara.

\section{Kompleks Makam Eyang Bagus Entol}

Kompleks Makam Eyang Bagus Entol terletak di Blok Panunggulan, Desa Sukahurip, Kecamatan Tamansari. Di sekeliling kompleks makam merupakan kebun dengan status kepemilikan merupakan lahan milik kelurahan.

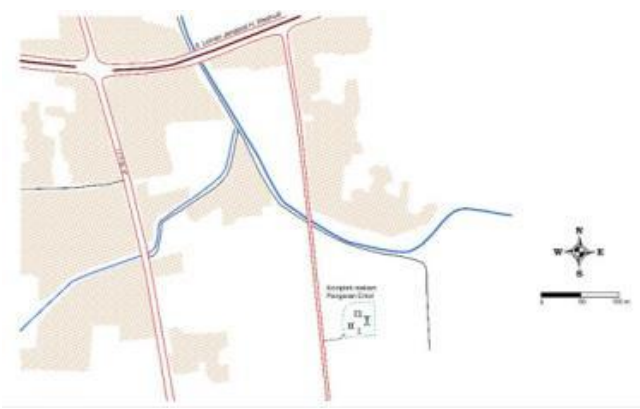

Gambar 7. Peta situasi Makam Eyang Bagus Entol (Sumber: Dokumen Balai Arkeologi Jawa Barat, 2018)

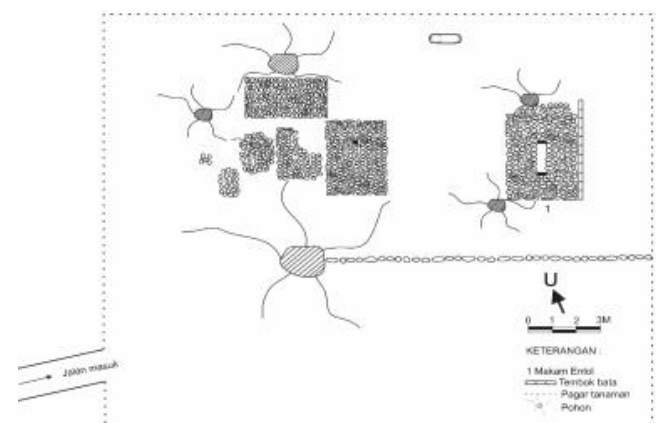

Gambar 8. Denah kompleks Makam Eyang Bagus Entol (Sumber: Dokumen Balai Arkeologi Jawa Barat, 2018)

Di lokasi tersebut terdapat 7 (tujuh)makam dengan makam utama berada pada posisi paling timur lahan, ditandai dengan nisan tipe Demak-Tralaya ${ }^{1}$. Makam-makam yang terdapat di tempat ini tersusun dari tatanan batu yang membentuk jirat. Kecuali nisan tokoh utama, nisan yang lain berupa batu alam yang diletakkan dengan posisi ditegakkan.

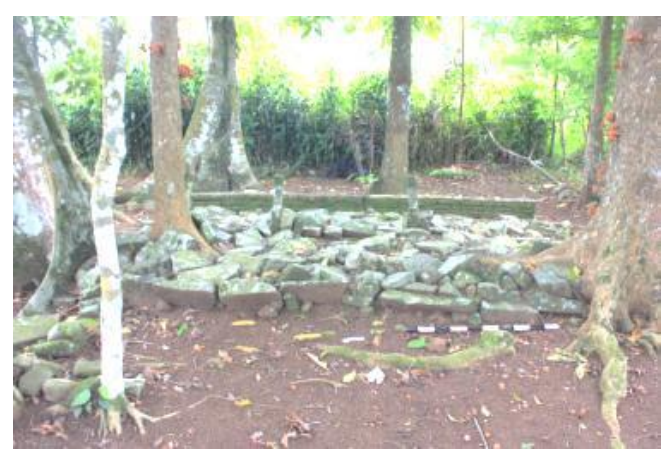

Gambar 9. Makam Eyang Bagus Entol ditandai dengan nisan tipe Demak-Tralaya (Sumber:

Dokumen Balai Arkeologi Jawa Barat, 2018)

\footnotetext{
${ }^{1}$ Menurut Lukman Nurhakim (1990) nisan tipe Demak-Tralaya terdiri dari tiga sub tipe. Sub tipe pertama ditandai dengan bentuk dasar segi empat pipih. Kepala nisan berundak berbentuk mahkota. Hiasan yang biasa digunakan berupa tumpal pada bagian badan dan kaki nisan. Sub tipe kedua berbentuk dasar bulat. Kepala nisan berbentuk lengkung yang menyatu dengan badan nisan, makin ke bawah makin mengecil. Hiasan yang sering digunakan berupa pelipit pada bagian kaki nisan. Nisan sub tipe ketiga mempunyai bentuk dasar pipih. Kepala nisan berbentuk kurawal menyerupai lengkung kala makara. Hiasan yang sering digunakan berupa hiasan pilin, hiasan tanaman pada bagian badan nisan, sedangkan bagian bawah nisan terdapat hiasan tumpal (Nurhakim, 1990: 80).
} 


\section{Kompleks Makam Situ Cibeureum}

Kompleks Makam Situ (kolam besar atau waduk) Cibeureum terletak di Blok Nusa Tamansari, Kelurahan Tamanjaya, Kecamatan Tamansari. Kompleks makam berada di sisi sebelah utara danau/situ. Lingkungan komplek makam berupa kebun talun.

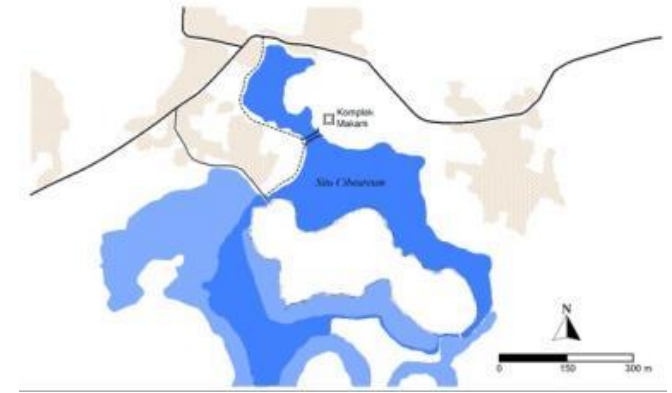

Gambar 10. Peta situasi situs Kompleks Makam Situ Cibeureum (Sumber: Dokumen Balai Arkeologi Jawa Barat, 2018)

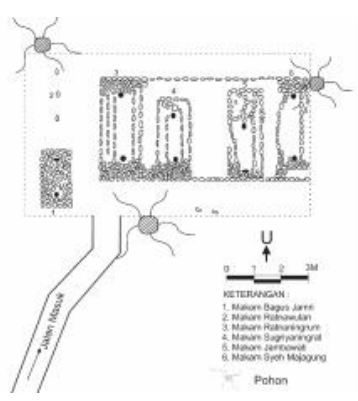

Gambar 11. Denah kompleks Makam Situ Cibeureum (Sumber: Dokumen Balai Arkeologi Jawa Barat, 2018)

Di Kompleks Makam Situ Cibeurem terdapat 5 (lima) makam. Menurut keterangan Atang (kuncen kompleks makam), kelima makam tersebut merupakan makam Syech Majagung, Jambawati, Sugriyaningrat, Ratna Ningrum, Ratna Wulan, dan Bagus Jamri. Bagus Jamri merupakan tokoh yang mengerjakan pembukaan Situ Cibeureum. Kecuali makam Ratnawulan, empat makam tersusun dari batu-batu kali yang ditata membentuk jirat yang dilengkapi nisan dari batu alam yang diletakkan dengan posisi ditegakkan. Sedangkan makam Ratnawulan hanya berupa 3 batu yang diletakkan berjajar.

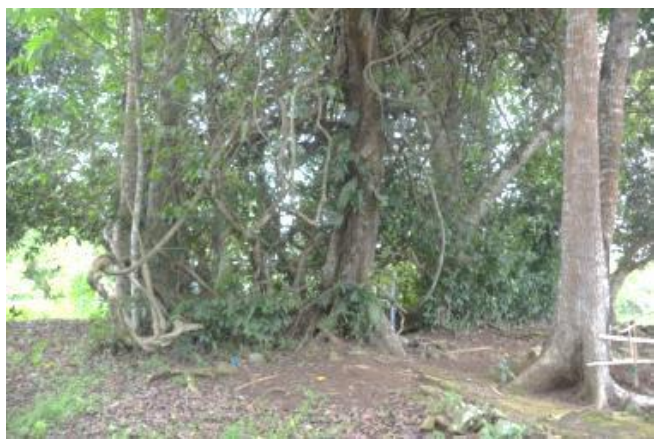

Gambar 12. Gerbang Kompleks Makam Situ Cibeureum (Sumber: Dokumen Balai Arkeologi Jawa Barat, 2018)

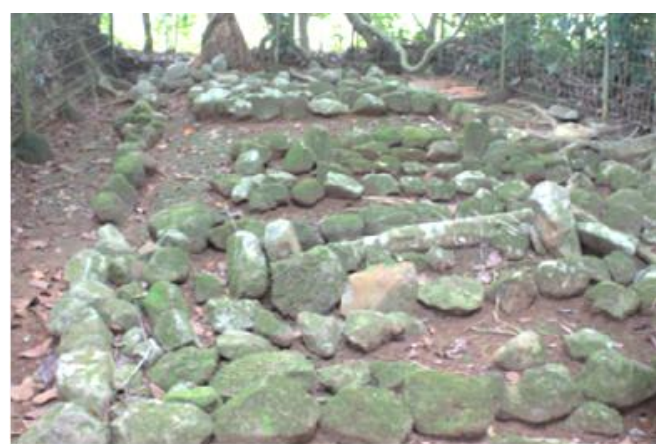

Gambar 13. Situasi makam-makam di Kompleks Makam Situ Cibeureum (Sumber: Dokumen Balai Arkeologi Jawa Barat, 2018)

\section{Penguburan dan Latar Belakang Konsep}

Penguburan merupakan serangkaian aktivitas yang banyak dilatari budaya. Penguburan atau pemakaman sudah dikenal sejak zaman prasejarah. Pada zaman pengaruh Islam, konsepsi penguburan juga dilandasi pada budaya masa prasejarah hingga pengaruh Hindu Buddha. Pada kasus makam-makam kuno di Tasikmalaya, salah satu latar belakang budaya yang dapat teramati adalah dari keletakan makam. Secara umum 
keletakan makam-makam kuno di Tasikmalaya adalah pada lokasi geografis yang berbeda yaitu pada tempat tinggi (bukit atau pasir) dan pada pedataran rata. Kompleks makam yang berada pada tempat tinggi misalnya tampak pada kompleks makam Gunung Subang dan kompleks makam Babakan Tempe.

Pemilihan tempat tinggi pada masa Islam sudah lazim dilakukan. Kompleks makam raja-raja Mataram di Imogiri berada pada puncak bukit. Pemilihan ini mengingatkan pada pemilihan lokasi untuk pendirian bangunan-bangunan suci pada masa pengaruh Hindu Buddha (Wiryomartono, 1995: 10). Pemilihan lokasi makam di puncak bukit juga dapat dijumpai di kompleks makam Desa Astana, Kecamatan Cirebon Utara, Cirebon. Di sini terdapat dua kompleks makam di atas bukit yang dipisahkan jalan raya Cirebon - Indramayu. Kompleks makam Sunan Gunung Jati di Gunung Sembung dan kompleks makam Syekh Datu Kahfi di Gunung Jati. Kedua kompleks makam ini berundak-undak. Makam utama berada di bagian paling atas (Ambary, 1985: 85). Pemilihan lokasi pada tempat tinggi merupakan kesinambungan konsepsi pada masa prasejarah, Hindu Buddha dan yang berlanjut pada masa Islam.

Pada zaman prasejarah, gunung dianggap sebagai tempat suci persemayaman para arwah. Bangunan-bangunan megalit sebagai sarana pengagungan arwah leluhur seringkali dijumpai di gunung atau tempat-tempat tinggi. Memasuki zaman klasik, peranan gunung dalam simbolisme kehidupan terlihat dalam landasan kosmogonis kerajaan-kerajaan kuno di Asia Tenggara. Robert von Heine Geldern dalam menelaah konsepsi ini mendapatkan gambaran bahwa kerajaan kuno di Asia Tenggara pada umumnya mempunyai kepercayaan akan adanya keserasian antara dunia manusia (mikrokosmos) dengan alam semesta (makrokosmos). Konsep kosmogonis ini berdasar pada doktrin agama Brahma dan Buddha. Menurut doktrin Brahma, jagad merupakan benua berbentuk lingkaran yang disebut Jambudwipa. Di tengah Jambudwipa berdiri kokoh Gunung Meru. Jambudwipa dikelilingi tujuh samodra dan tujuh benua lainnya. Di luar samodra terakhir terdapat jajaran pegunungan. Menurut doktrin Buddha, Gunung Meru sebagai pusat jagad raya, dikelilingi tujuh barisan pegunungan masing-masing dipisahkan tujuh samodra. Di luar jajaran pegunungan yang paling luar terletak lautan. Di lautan ini terdapat empat benua yang berada pada empat penjuru mata angin. Benua yang berada di sebelah selatan Gunung Meru adalah Jambudwipa tempat tinggal manusia (Geldern, 1982: 1-5).

Konsep tentang meru juga diimplementasikan dalam pertunjukan wayang. Replika gunung yang disebut gunungan atau kekayon, selalu digunakan untuk mengawali dan mengakhiri secara menyeluruh atau sebagian adegan (Behrend, 1982: 168). Lakon dalam wayang merupakan gambaran perjalanan hidup manusia. Demikian juga dengan gunungan dalam wayang, selain sebagai tanda diawali dan diakhirinya adegan dan lakon wayang, juga sebagai simbol awal dan akhirnya kehidupan. Manusia berasal dari gunung dan berakhir di gunung. Penempatan makam pada gunung atau tanah tinggi menggambarkan akhir kehidupan manusia.

Kompleks makam di Tasikmalaya pada kajian ini yang berada di bukit atau lahan tinggi adalah kompleks makam Gunung Subang dan kompleks makam Babakan Tempe. 
Di kompleks makam Gunung Subang tokoh utama yang dimakamkan Embah Kamasan, Embah Anjung, dan Embah Kalijaga. Di kompleks makam Babakan Tempe terdapat makam Amirudin, Embah Nangga, dan Amburudin. Bagaimana peran tokoh ini di masyarakat pada masanya belum dapat diketahui. Data pendukung berupa teks atau cerita lisan juga tidak ditemukan. Berdasarkan dua kompleks makam ini hanya diketahui bahwa konsep pemilihan lokasi pemakaman mengikuti konsep bahwa tempat tinggi merupakan tempat suci tempat akhir kehidupan.

Selain pada gunung, makam kuno di Tasikmalaya juga ada yang berada di pedataran, yaitu kompleks makam Situ Cibeureum dan Eyang Bagus Entol. Menurut cerita tutur, kedua makam ini ada keterkaitan dengan penyebaran agama Islam dan pembuatan situ. Keterangan tentang Eyang Bagus Entol terkait dengan beberapa artefak yang disimpan Didi, yang beralamat di RT 01/03 Kelurahan Cilamajang, Kecamatan Kawalu. Menurut penjelasan Didi, benda-benda tersebut merupakan pemberian dari keturunan Eyang Entol. Barang-barang tersebut berupa beberapa barang keramik berbentuk cepuk, piring, mangkuk, teko, dan naskah tulisan tangan.

Naskah tulisan tangan menggunakan media buku tulis dengan jenis kertas HVS bergaris berukuran A6 (10,5 x 14,8 cm). Teks ditulis dengan dua aksara. Bagian atas aksara Arab pegon dan di bawahnya aksara latin. Pada bagian akhir terdapat keterangan bahwa naskah tersebut merupakan salinan dari naskah salinan pula. Naskah asli tidak diketahui. Naskah salinan ditulis oleh H. Bajuri yang kemudian disalin lagi oleh Muhammad Sujai bin Muhammad Gojali bin Muhammad Raden Salwi bin Embah Angga bin Embah Entol bin Pangeran Eyang Papak Al Mataram Islam. Disalin di Karanganyar, Kawalu, Tasikmalaya pada 4-2-'70 Masehi bertepatan dengan 26-11-'89 Hijrah. Untuk sementara naskah ini disebut dengan Naskah Cibeureum.

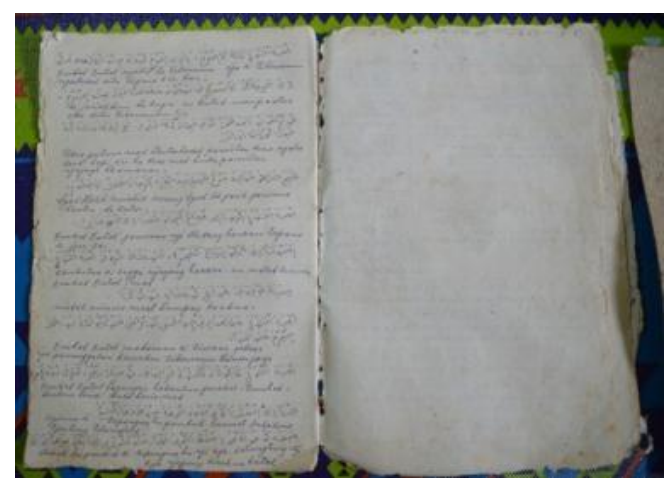

Gambar 14. Naskah kuno tentang Embah Entol (Sumber: Dokumen Balai Arkeologi Jawa Barat, 2018)

Isi naskah pada awalnya berupa keterangan tentang penahanan Pangeran Diponegoro, Imam Bonjol, dan Haji Saka yang diasingkan oleh Belanda ke Ambon. Selanjutnya keterangan tentang Embah Entol, Syech Hatib Muwahid, dan Syech Abdul Gorib yang berasal dari Demak. Mereka adalah putra Eyang Pangeran Papak. Mereka dikejar-kejar Belanda dan mengungsi ke Saguling. Syech Hatib Muwahid pindah ke 
Panyalakan ikut Kanjeng Syech Abdul Muhyi. Di Saguling Syech Hatib Muwahid mempunyai putra bernama Eyang Malaka. Makam Eyang Malaka di Gunung Malaka, Saguling.

Syech Abdul Gorib makamnya di Cibeas. Embah Entol pindah ke Cibeureum. Di Cibeureum membuka (ngabedah) situ yang luasnya 250 bau. $^{2}$ Situ tersebut kemudian pengerjaannya diserahkan kepada Sugri. Putra dan cucu Embah Entol kalau akan memanfaatkan situ tidak perlu minta izin tetapi kalau orang lain harus minta izin untuk menjaga keamanan. Isteri Embah Entol bernama Nyi Medang Kancana. Embah Entol dimakamkan di Ciwaas, Gobras, Cibeureum. Benda-benda peninggalan Embah Entol berupa tombak, kendi, dan mungkin keris. Benda-benda itu dipegang oleh salah seorang warga Sukadua, Genteng, Cilamayang.

Berdasarkan isi naskah, peristiwa pembukaan Situ Cibeureum berlangsung sesudah perang Jawa (perang Diponegoro). Tokoh-tokoh yang disebutkan Embah Entol, Syech Hatib Muwahid, dan Syech Abdul Gorib. Mereka berasal dari Demak putra Eyang Pangeran Papak. Tokoh dengan nama Papak terdapat pada sejarah perlawanan di daerah Jawa Tengah.

Pada 1746 - 1755 di Jawa terjadi perang Mangkubumi antara pihak Mataram melawan VOC. Salah satu tokoh dalam peperangan itu adalah Panembahan Natapraja. Dalam berperang Panembahan Natapraja dibantu dua anaknya yang disebut Putera Natapraja dan Kustiah. Ketika peperangan berlangsung, Panembahan Natapraja diperintahkan oleh Mangkubumi untuk berhenti berperang. Pada 15 Februari 1755, di Desa Giyanti (antara Solo dan Madiun) diadakan perjanjian antara Kompeni Belanda (V.O.C), Sunan Pakubuwono III, dan Pangeran Mangkubumi. Perjanjian tersebut terkenal dengan nama "Perjanjian Giyanti" yang keputusannya adalah wilayah Mataram dibagi dua antara Pakubuwono dan Mangkubumi. Pangeran Mangkubumi kemudian diakui sebagai Sultan Yogyakarta yang pertama bergelar Sultan Hamengkubuwono I. Panembahan Natapraja tunduk kepada Pangeran Mangkubumi tetapi tidak mau tinggal di keraton. Panembahan Natapraja memilih tinggal di Serang.

Setelah perang Mangkubumi berakhir, pada 1825 - 1830 berkobar perang Jawa atau lebih dikenal dengan Perang Diponegoro. Di Serang Panembahan Natapraja membangun kekuatan untuk memihak kepada Pangeran Diponegoro. Pihak V.O.C. mengetahui akhirnya diserang dan Putera Natapraja gugur. Panembahan Natapraja yang mendekati usia lanjut akhirnya meninggal dunia. Kustiah kemudian kembali masuk ke lingkungan keraton Yogyakarta. RM. Sundoro sebagai putera mahkota berniat memperistri Kustiah, namun Kustiah menolak dengan halus. Kustiah kemudian mendapat sebutan R.A. Kustiah Wulaningsih Retno Edi. R.A. Kustiah kemudian menikah dengan Pangeran Mutia Kusumawijaya dan mendapat keturunan yang diberi nama Kustina. R.M. Sundoro yang kemudian bergelar Sultan Hamengku Buwono II teringat kepada R.A. Kustiah yang berada di Desa Serang. Sultan ingin melangsungkan hubungan batin dengan R.A. Kustiah. Sultan Hamengku Buwono II kemudian menjodohkan puteranya yang

\footnotetext{
${ }^{2}$ Satuan bahu banyak digunakan untuk areal pertanian (sawah atau ladang) dan telah dipakai sejak zaman Hindia Belanda. Menurut Cultuurstelsel, 1 bouw (bahu) adalah 7096,5 m².
} 
bernama Pangeran Aria Adipati Mangkudiningrat dengan Kustina. R.A. Kustiah akhirnya menjadi besan dari Sultan Hamengku Buwono II. Perkawinan antara Pangeran Mangkudiningrat dengan Kustina menurunkan R.M. Papak yang kemudian dikenal sebagai Pangeran Notoprojo atau Pangeran Aria Papak (Lasminah, 2007). Berdasarkan sejarah Nyi Ageng Serang, Pangeran Papak berasal dari Desa Serang, Jawa Tengah. Dalam Naskah Cibeureum disebutkan Pangeran Papak berasal dari Demak. Hal ini dapat diterima karena Pangeran Papak masih keturunan Sunan Kalijaga dari Kadilangu, Demak.

Di dalam Naskah Cibeureum juga menyebut nama Syech Abdul Gorib yang juga berasal dari Demak kemudian dimakamkan di Cibeas. Makam Syekh Abdul Ghorib berada pada pebukitan di Kampung Cibeas, Desa Gunung Tandala, Kecamatan Kawalu Kota Tasikmalaya, Provinsi Jawa Barat. Syekh Abdul Ghorib, dilahirkan di daerah Kudus pada sekitar tahun 1655 M (1076 H). Syekh Abdul Ghorib belajar agama kepada ulamaulama di Jawa dan Sumatera. Ilmu agama diperdalam di Mekah sekalian melaksanakan ibadah haji. Sekembali dari Mekah mendirikan pesantren di Kudus. Isteri Syekh Abdul Ghorib bernama Rd. Ajeng Ayu Sutri. Pesantren yang didirikannya berkembang dan begitu kuat dibubarkan oleh pihak Belanda (VOC) karena dikhawatirkan dapat mengganggu kekuasaan Belanda. Syekh Abdul Ghorib kemudian pindah ke Jawa Barat. Di Jawa Barat bertemu dengan Syekh Abdul Muhyi di Pamijahan. Pada sekitar 1708 M (1129 H) mendirikan pesantren di Tasikmalaya. Lokasi pesantren berada pada daerah yang dikelilingi pegunungan. Dengan adanya pesantren, daerah tersebut kemudian berkembang menjadi kampung yang dinamakan Kampung Pasantren. Kampung Pasantren kemudian berganti nama menjadi Kampung Cibeas (Tim Penelitian, 2012).

Bertalian dengan Syekh Abdul Ghorib, di Cibeureum Embah Entol membuka situ Cibeureum. Unsur air merupakan hal yang sangat penting dalam pembinaan permukiman dalam skala makro. Menurut geomantik Jawa, kota harus didirikan di daerah yang cukup air. Penguasa yang akan mendirikan sebuah kota baru harus dapat menunjukkan kemampuannya di bidang irigasi dan drainase. Hal itu juga merupakan tantangan bagi penguasa untuk menaklukkan alam bebas guna mensejahterakan pengikutnya (Santoso, 2008: 167). Air memegang peran penting dalam konsep kekuasaan. Pada masyarakat petani, air merupakan unsur vital untuk manusia dan pertanian. Sistem pengairan yang dilakukannya menimbulkan sistem kepemimpinan. Teori Oriental Despotism yang diajukan Karl Wittfogel, berisi tentang hydraulic society yang diambil dari studi tentang adanya despotisme dalam masyarakat pengguna air sungai di sekitar sungai-sungai Nil, Indus, dan Yang Tse Kiang. Di sana bisa muncul raja yang berkuasa mutlak untuk membagikan air (Wittfogel, 1957: 25). Secara tradisional, masyarakat Bali mengenal sistem organisasi subak untuk mengatur air (Geria, et al., 2019).

Dalam sejarah kuno Jawa Barat, di dalam prasasti Tugu disebutkan bahwa pada tanggal 8 paro-petang bulan Phalguna dimulai penggalian Sungai Gomati yang mengalir di lahan tempat tinggal Sang Pendeta nenek Sang Purnawarman (Poesponegoro dan Notosusanto, 2009: 52-53). Prasasti Tugu mengisyaratkan bahwa air, baik untuk irigasi maupun prasarana transportasi, merupakan unsur penting dalam melanggengkan kekuasaan Raja Purnawarman. Aktivitas penyediaan air juga dilakukan oleh Raja 
Wastukancana. Pada prasasti Kawali I disebutkan bahwa Prabu Raja Wastu membuat parit irigasi di sekeliling kota (Nastiti dan Djafar, 2016).

Pada masa kolonial, salah satu usaha para bupati untuk mempertahankan kekuasaan tradisionalnya terhadap rakyat dapat dilakukan melalui proyek-proyek yang ada hubungannya dengan air. Air secara tidak langsung dijadikan senjata untuk melawan pemerintah kolonial, di lain sisi untuk merangkul rakyat pribumi. Bupati Galuh, telah membangun prasarana pertanian dan perkebunan dalam rangka melawan pemerintah kolonial. Pada 1677 di daerah Priangan diterapkan Preangerstelsel. Para bupati diperintahkan mengharuskan rakyatnya untuk menanam kopi. Di Kabupaten Galuh, rakyat selain dipaksa menanam kopi juga diharuskan menanam nila. Bupati Galuh menolak dan memerintahkan rakyat untuk mengembangkan pertanian dan perkebunan. Bangunan untuk kesejahteraan rakyat dibuat antara lain saluran air dan bendungan untuk irigasi sawah. Areal persawahan baru dibuka di mana-mana. Selain bersawah, Kangjeng Prabu memerintahkan rakyat untuk menanam kelapa. Setiap calon pasangan yang akan menikah diwajibkan membawa dua butir tunas kelapa (kitri) untuk ditanam di halaman rumahnya. Dengan cara seperti itu perkebunan kelapa mengalami perkembangan pesat sehingga dikenallah Ciamis sebagai gudang kelapa (Lubis, 2013). Bendungan dan saluran irigasi yang dibuat oleh Kangjeng Prabu antara lain adalah bendungan Nagawiru. Bendungan ini membendung Ci Leueur di perbatasan Desa Sukajadi dan Imbanegara, Kecamatan Imbanegara, Ciamis. Struktur bendungan berupa check dam yang membendung sungai sehingga permukaan air naik. Struktur check dam dari susunan batu kali berbentuk persegi (Saptono, 2018).

Dalam masyarakat primordial pertanian, air adalah kehidupan. Tidak ada air berarti tidak ada kehidupan. Cara berpikir petani adalah cara berpikir pertanian. Nilai tertinggi kehidupan adalah air untuk pertanian. Air hujan, sungai, letak tanah, kesuburan tanaman, hama, mata air, hutan, dan gunung adalah sistem pengetahuan mereka yang utama. Masyarakat peladang dan masyarakat penyawah sedikit berbeda dalam memahami air. Masyarakat peladang sangat menghargai air hujan sedangkan penyawah cenderung lebih mementingkan sungai. Meskipun demikian kedua kelompok masyarakat ini sadar sama-sama memelihara hutan dan sungai untuk menjaga air. Pada masyarakat Sunda, sumur jarang dikenal. Mereka cenderung memanfaatkan mata air di tepi sungai atau batubatu cadas di tebing pinggir hutan. Dalam konsep dewa-dewa (hyang), masyarakat Baduy Sang Hyang Tunggal merupakan dewa tertinggi. Dia berputrakan 7 batara di antaranya adalah Batara Patanjala sebagai dewa air (Sumardjo, 2011: 71-73).

Kaitan antara unsur air dengan pertanian di dalam Naskah Cibeureum yang perlu dicermati adalah istilah ngabeudah situ. Pekerjaan mirip ngabeudah situ juga pernah dilakukan oleh Dalem R.A.A. Wiratanuningrat pada tahun 1925 membuka (ngabukbak) Rawa Lakbok untuk dijadikan area pesawahan yang luasnya 30.000 bau. Peristiwa ini tertuang di dalam naskah Ngabukbak Lakbok yang ditulis oleh R. Muhammad Sabri Wiraatmadja. Naskah kuno berupa buku tulis bergaris. Teks berupa tulisan tangan beraksara Arab pegon, Sunda, dan Latin. Isi teks merupakan catatan peristiwa sejak mulai dibukanya rawa hingga bermanfaat (Bastaman, 2004). Berdasarkan Naskah Cibeureum 
dan Naskah Ngabukbak Lakbok, ngabeudah dapat diartikan membuka kawasan rawa yang semula tidak dimanfaatkan masyarakat untuk dimanfaatkan sehingga dapat memberikan hasil kepada masyarakat. Pemanfaatan di Rawa Lakbok cenderung untuk usaha pertanian, sedangkan di Situ Cibeureum untuk memelihara ikan di samping juga untuk mengairi sawah.

Pembukaan Situ Cibeureum menurut Naskah Cibeureum dilakukan oleh Embah Entol, sedangkan menurut cerita lisan yang berkembang adalah Bagus Jamri. Perbedaan ini dapat dipahami bahwa dengan mempertimbangkan kedudukan dan data, Embah Entol sebagai pemrakarsa sedangkan Bagus Jamri adalah pelaksana. Di dalam Naskah Cibeureum disebutkan bahwa pengerjaan dilakukan oleh Sugri.

Di situs kompleks Makam Cibeureum terdapat makam dengan tokoh penting yang dimakamkan adalah Syekh Majagung. Nama Syekh Majagung memang kurang begitu dikenal dalam jajaran "orang-orang keramat" yang disebut walisongo. Pada beberapa naskah kuno tentang wali, jumlah wali berbeda-beda namun tetap saja disebut walisongo. Nama Syekh Majagung diantaranya disebutkan dalam naskah Musyawarah Para Wali, Babad Tanah Jawi versi tembang, Sajarah Banten, Babad Cirebon, Babad Demak, Serat Kanda, Serat Centini, dan masih banyak lagi. Pada beberapa naskah nama Syekh Majagung disebut dengan beberapa gelar sebutan yaitu Pangeran Majagung, Seh Majagung, Kangjeng Susuhunan Majagung, Susuhunan ing Majagung, dan mungkin juga Pangeran Jagung sebagaimana pada naskah Babad Cirebon (Montana, 1988). Menilik pada beberapa naskah kuno, Syekh Majagung merupakan salah satu wali. Mengenai keberadaan makam Syekh Majagung di kompleks makam Cibeureum menunjukkan bahwa daerah Tasikmalaya juga mendapat pengaruh ajarannya. Makam Syekh Majagung di kompleks makam itu cenderung bukan sebagai makam dalam arti kuburan tetapi merupakan petilasan.

\section{SIMPULAN}

Di Tasikmalaya terdapat banyak makam tokoh dari masa Islam. Dilihat dari keletakannya, makam-makam tersebut ada yang berada di puncak bukit (lahan tinggi) ada pula yang di pedataran. Kompleks makam yang berada di bukit sebagai contoh adalah kompleks makam Gunung Subang dan Babakan Tempe. Tokoh yang dimakamkan di Gunung Subang adalah Embah Kamasan, Embah Anjung, dan Embah Kalijaga. Di kompleks makam Babakan Tempe, atau disebut juga kompleks makam Gunung Gede tokoh yang dimakamkan adalah Amirudin, Embah Nangga dan Amburudin. Tokoh-tokoh tersebut tidak diketahui latar belakangnya. Baik di kompleks makam Gunung Subang maupun Babakan Tempe memperlihatkan adanya konsep gunung sebagai tempat suci dan akhir kehidupan sebagai pertimbangan untuk pemilihan lokasi pemakaman.

Selain kompleks makam yang berada di puncak bukit, juga dijumpai kompleks makam di pedataran yaitu kompleks makam Eyang Bagus Entol dan kompleks makam Situ Cibeureum. Beberapa tokoh utama yang dimakamkan ternyata ada saling keterkaitan. Keterangan tentang tokoh-tokoh yang dimakamkan dapat diketahui melalui naskah tulisan tangan yang tersimpan pada Didi, penduduk kelurahan Cilamajang. Pada naskah 
selain menguraikan latar belakang tokoh, juga terdapat keterangan mengenai pembukaan situ Cibeureum. Berdasarkan naskah dan beberapa literatur pendukung, tokoh Eyang Entol merupakan pemrakarsa pembukaan situ Cibeureum. Eyang Entol merupakan keturunan Pangeran Papak, cucu Nyi Ageng Serang yang merupakan kerabat keraton Mataram Islam.

\section{UCAPAN TERIMA KASIH}

Terima kasih penulis ucapkan kepada Dede Rahmat dari Yayasan Tapak Karuhun Nusantara yang telah membantu dan memberikan informasi selama berlangsungnya kegiatan pengumpulan data di lapangan.

\section{DAFTAR PUSTAKA}

Ambary, H. M. (1985). Historical Monuments. In P. R. Abdurachman (Ed.), Cerbon (pp. 68-91). Jakarta: Yayasan Mitra Budaya Indonesia - Sinar Harapan.

Ambary, H. M. (1991). Makam-makam Kesultanan dan Parawali Penyebar Islam di Pulau Jawa. Aspek-aspek Arkeologi Indonesia No. 12. Jakarta: Pusat Penelitian Arkeologi Nasional.

Bastaman, H. D. (2004). R.A.A. Wiratanuningrat Jeung Rawa Lakbok: Dumasar kana Naskah "Ngabukbak Lakbok" karya R. Muh. Sabri Wiraatmadja. In Bupati di Priangan dan Kajian Lainnya Mengenai Budaya Sunda. Seri Sundalana 3 (pp. 67-88). Bandung.

Behrend, T. E. (1982). Kraton and Cosmos in Traditional Java. University of Wisconsin.

Geldern, R. von H. (1982). Konsepsi Tentang Negara \& Kedudukan Raja di Asia Tenggara. Jakarta: C.V. Rajawali.

Geria, I. M., Sumardjo, nfn, Sutjahjo, S. H., Widiatmaka, nfn, \& Kurniawan, R. (2019). Subak sebagai Benteng Konservasi Peradaban Bali. AMERTA, 37(1), 39-54.

KONDISI GEOGRAFI KOTA TASIKMALAYA. (2018).

Lasminah, P. (2007). Nyi Ageng Serang. Jakarta: Departemen Kebudayaan dan Pariwisata, Direktorat Jenderal Sejarah dan Purbakala, Direktorat Nilai Sejarah.

Lubis, N. H. (2013). Sejarah Kabupaten Ciamis. Bandung: Dinas Pariwisata dan Kebudayaan Provinsi Jawa Barat.

Montana, S. (1988). Studi Perbandingan Naskah Islamologi Tentang Orang-orang Keramat Pada Zaman "Kuwalen” di Jawa. Berkala Arkeologi, IX (1), 38-63.

Nastiti, T. S., \& Djafar, H. (2016). Prasasti-prasasti dari Masa Hindu-Buddha (Abad ke12 - 16 Masehi) di Kabupaten Ciamis, Jawa Barat. PURBAWIDYA: Jurnal Penelitian Dan Pengembangan Arkeologi, 5(2), 101-116.

Nurhadi. (1990). Arkeologi Kubur Islam di Indonesia. In Analisis Hasil Penelitian Arkeologi I: Religi Dalam Kaitannya Dengan Kematian Jilid I (pp. 137-156). Jakarta: Departemen Pendidikan dan Kebudayaan.

Nurhakim, L. (1990). Tinjauan Tipologi Nisan Pada Makam Islam Kuno di Indonesia. In 
R. . Soejono (Ed.), Analisis Hasil Penelitian Arkeologi I, Religi Dalam Kaitannya Dengan Kematian Jilid II (pp. 75-84). Jakarta: Pusat Penelitian Arkeologi Nasional, Departemen Pendidikan dan Kebudayaan.

Poesponegoro, M. D., \& Notosusanto, N. (2009a). Sejarah Nasional Indonesia I. Zaman Prasejarah. Jakarta: Balai Pustaka.

Poesponegoro, M. D., \& Notosusanto, N. (2009b). Sejarah Nasional Indonesia II, Zaman Kuno. Jakarta: Balai Pustaka.

Rasjid, S. (1992). Fiqh Islam. Bandung: Sinar Baru.

Redaksi, T. (2005). Kamus Besar Bahasa Indonesia. Jakarta: Balai Pustaka.

Santoso, J. (2008). Arsitektur-kota Jawa: Kosmos, Kultur \& Kuasa. Jakarta: Centropolis - Magister Teknik Perencanaan Universitas Tarumanagara.

Saptono, N. (2018). Tata Ruang Kota Ciamis Pasca perdagangan Dunia Abad Ke-19 20. Panalungtik, 1(1), 41-60.

Suhadi, M., \& Hambali, H. (1995). Makam-makam Wali Songo di Jawa. Jakarta: Departemen Pendidikan dan Kebudayaan.

Sumardjo, J. (2011). Sunda: Pola Rasionalitas Budaya. Bandung: Kelir.

Tim penelitian. (2012). Laporan Penelitian Arkeologi Tentang Potensi Tinggalan Arkeologi di Kota Tasikmalaya. Bandung.

Umiarti, A. T., \& Sukana, M. (2016). Desa Trunyan: Pengalaman Wisata Penuh Makna. Denpasar: Pustaka Larasan.

Widyastuti, E., \& Boedi, O. B. (2018). Nilai Penting Kompleks Makam Syeh Tubagus Abdullah Dan Balung Tunggal di Kecamatan Purbaratu, Kota Tasikmalaya. Panalungtik, 1(1), 27-40.

Wiryomartono, A. B. P. (1995). Seni Bangunan dan Seni Binakota di Indonesia: Kajian Mengenai Konsep, Struktur, dan Elemen Fisik Kota Sejak Peradaban HinduBuddha, Islam Hingga Sekarang. Jakarta: PT GramediaPustaka Utama.

Wittfogel, K. A. (1957). Oriental Despotism, a Comparative Study of Total Power. New Have: Yale University Press. 